\title{
Agricultural intensification, ownership, and landscape change in the Mackenzie Basin
}

\author{
A.L. BROWER ${ }^{1}$, R. SPRAGUE ${ }^{2}$, M. VERNOTTE ${ }^{3}$ and H. McNAIR ${ }^{1}$ \\ ${ }^{1}$ Department of Geography, University of Canterbury, New Zealand \\ ${ }^{2}$ Bio-Protection Research Centre, PO Box85084, Lincoln University, Lincoln 7647, Canterbury, New Zealand \\ ${ }^{3}$ AgroSup Dijon, 26 boulevard Petitjean, BP87999, 21079 - Dijon cedex, France \\ ann.brower@canterbury.ac.nz
}

\begin{abstract}
This article investigates the role of shifting land ownership in landscape change in New Zealand's Mackenzie Basin. It was hypothesised that ownership patterns influence landscape transformation; and changes in ownership lead to landscape changes. Satellite imagery was used to trace recent landscape changes quantifying a change from brown extensive pastoralism to green irrigated pasture. It was concluded that the change in land ownership following land reform allowed for about half of this agricultural intensification since 2003. Aggregating intensification on new freehold land with that on current pastoral lease changes the story; Crown decisions about disposition or intensification of Crown land account for twothirds of intensification since 2003. Hence, if current trends in the Mackenzie are to change, the Crown must examine its decision patterns. Change in some form seems likely. The results presented speak to who has the power to make change. The choice and the power reside somewhere in the space between the Commissioner of Crown Lands and the Minister of Land Information.
\end{abstract}

Keywords: pastoral leases, land ownership, environmental impacts

\section{Introduction}

There is something special about the Mackenzie (see Figure 1). Descending Burke's Pass is like walking into Narnia. But the Mackenzie is changing. Its vast expanses of tussock grasslands, formerly known for dryland sheep farming, are now home to dairy cows, deer farms, irrigated sheep pasturage, and residential subdivision, transforming landscapes that have been brown for generations (Brower \& Page 2017). Though some might see the arid Mackenzie as 'empty,' the landscape has a deep, rich, and long history actively shaped by human hands. Recently, the residential subdivisions proliferating around the townships of Tekapo and Twizel are echoing 'Icebreaker' in capitalising on these long histories to brand their subdivisions (Anthony 2018; Merino Downs 2018).

Many now say the Mackenzie is in trouble. The media call it a train wreck, Ngāi Tahu call it a disaster, the Environment Court says it's vulnerable, farmers

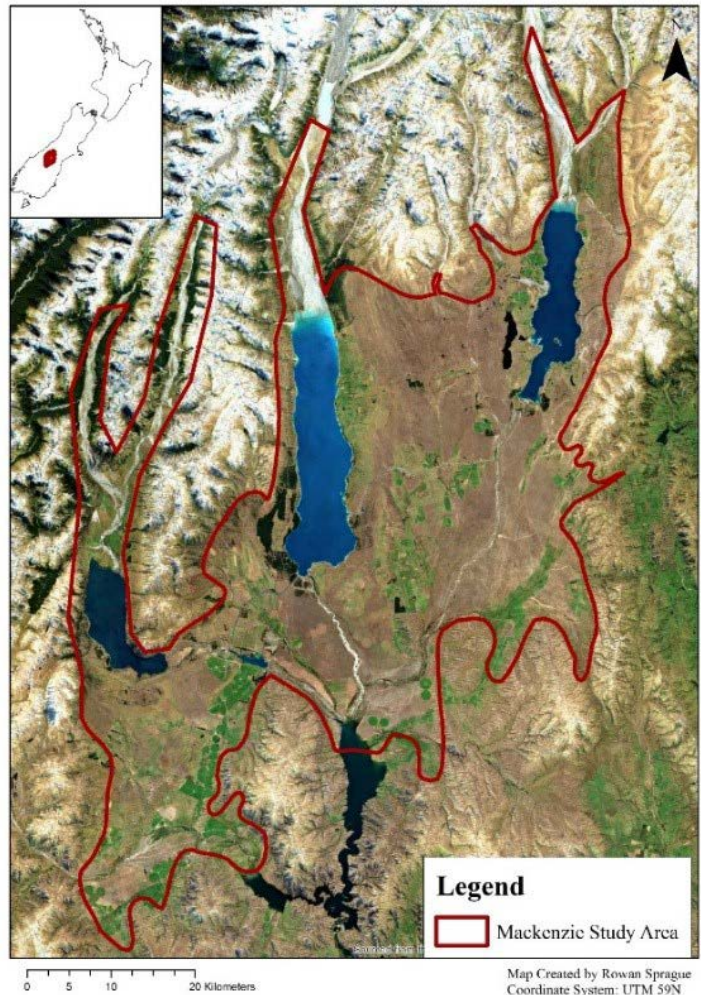

Figure 1 Satellite imagery of the Mackenzie Basin Study Area.

feel forced to irrigate, and the Minister of Land Information points to a 'biodiversity crisis'(Williams 2017; Littlewood 2018a, 2018b, 2018c; MacLean 2018; Mitchell 2018a). This paper, explores how much of this perceived crisis is associated with changes in land ownership through a land reform process called tenure review (Brower et al. 2010; Brower \& Page 2017; Mitchell 2018b, 2018c, 2018d; Timaru Herald 2018; Williams 2018d), and considers how changes in ownership are contributing to agricultural intensification and landscape change.

\section{Background}

From the middle of the 19th to the beginning of the 21st Century, over half of the Mackenzie Basin's quarter 
of a million hectares was owned by the Crown (New Zealand Government) and run as extensive dryland pastoral rangeland under Crown pastoral leases. The 1948 Land Act prohibited subdivision, industrial development, and post-pastoral land conversions of any kind without 'discretionary consent' from the Commissioner of Crown Lands (Brower \& Page 2017).

In the early 1990 s, the Crown started a voluntary land reform called tenure review, as authorised by the Crown Pastoral Land Act in 1998. Tenure review splits pastoral land between freehold and public conservation land, with the aim of 'freeing' productive lands from pastoral-only constraints, limits on conservation and recreational uses. Between 1991 and 2017, 371842 ha of South Island land has shifted to public conservation, and 436652 ha has become freehold. One-fifth of this land (74 000 ha) has since been on-sold on the open market for \$275 million; fetching a median price over 500 times the Crown's freeholding price.

The first of the Mackenzie's pastoral leases completed tenure review in 2003. This is when observations started. Since 2003, 88336 ha have been (or are proposed) to become freehold and 63303 ha have (or proposed) shifted into public conservation land (Brower \& Page 2017). One-quarter of the Mackenzie land the Crown freeholded for $\$ 540000$ has been on-sold for \$27.5 million (Brower \& Page 2017).

\section{Methods}

Imagery data were gathered from the following sources: Landsat-7 satellite from Earth Explorer, Land Information New Zealand aerial imagery, and Sentinel 2A satellite imagery from Earth Explorer. Three spectral bands (red, green, and blue) were used in the land use classification (see Table 1). Other studies have used Landsat imagery of this resolution to map changes in land cover over time, setting a strong precedent for its use in this study (Peterson \& Aunap 1998; Seto et al. 2002; Li \& Yeh 2004; Hansen et al. 2013).

Although the satellite imagery varies in its resolution, the scale at which land use changed was large, making it easily detectable. Additionally, although studies have found that $1 \mathrm{~m}$ resolution imagery is ideal, $30 \mathrm{~m}$ resolution imagery is still relatively accurate for land use change of this magnitude (see Fisher et al. 2018).

\section{Table 1}

Sources and specifications of imagery.

\begin{tabular}{llc}
\hline Date & Source of imagery & Spatial resolution $(\mathbf{m})$ \\
\hline 2003 February & Landsat-7 satellite & 30 \\
2008 February & Land Information NZ aerial imagery & 0.75 \\
2014 (February - March) & Land Information NZ aerial imagery & 0.5 \\
2018 (January) & Sentinel 2A satellite & 10 \\
\hline
\end{tabular}

To delineate land use change over time, land use change was classified as follows: uncultivated to cultivated land use; non-irrigated to irrigated land use; cultivated or irrigated land use that became uncultivated; and land developed for residential or commercial purposes. Polygons were drawn around the areas where land use changes were identified (after Grove et al. 2015) for the following time intervals: 2003-2008; 2008-2014; and 2014-2018. Types of intensification were not identified; and there was no land that reverted from intensified to uncultivated. All of the polygon delineations and summations of area were done in ArcGIS 10.5 (ESRI).

Boundaries of each ownership type in the Mackenzie Basin were mapped according to the following types: Freehold as of 2003, when observations began; Public Conservation Land as of 2003 (managed by DOC); current (as of 2018) Pastoral Lease land (Crown owned and leased to runholders); new Freehold land (land converted to Freehold through the Tenure Review); new Conservation land (converted to Public Conservation Land through Tenure Review); and land held by Ministry of Defence. Data was gathered from the following sources: LINZ (for pastoral lease boundaries and new Freehold and New Conservation land boundaries); and Koordinates.com (for Conservation as of 2003). Paper maps were used to manually digitise new boundaries of stations for which no spatial data were received from DOC.

\section{Results}

In less than 15 years, intensified land use in the Mackenzie more than doubled in extent. From 2014 to 2017, there were significant accelerations in intensification in the categories of new freehold and current pastoral lease. The remaining categories of ownership followed steady trends. 'Freehold as of 2003 ' had a head start, but most of the growth in intensification was on new freehold land. Further, the 'new freehold' category is growing in extent. In other words, intensification is shifting from old freehold to new freehold and pastoral lands. Of the approximately 20000 ha intensified in the Basin by 2003, 12000 ha were already under freehold title. Since 2003, intensification on existing freehold land has slowed; yet it has accelerated on new freehold and pastoral land, as illustrated by the 9000 ha of intensification on current pastoral leases and 16000 ha of intensification in new freehold land by 2017. Figure 2 summarises this situation, and Table 2 quantifies it.

As such, pastoral land 
management decisions by central government (be they decisions to grant freehold title, or decisions to grant discretionary consent to intensify while under pastoral lease) account for less than half of the total intensification in the Basin by 2003. Collectively, these pastoral land decisions open the door to two-thirds (17 $000 \mathrm{ha})$ of the 25000 ha growth of intensification in the Mackenzie between 2003 and 2017.

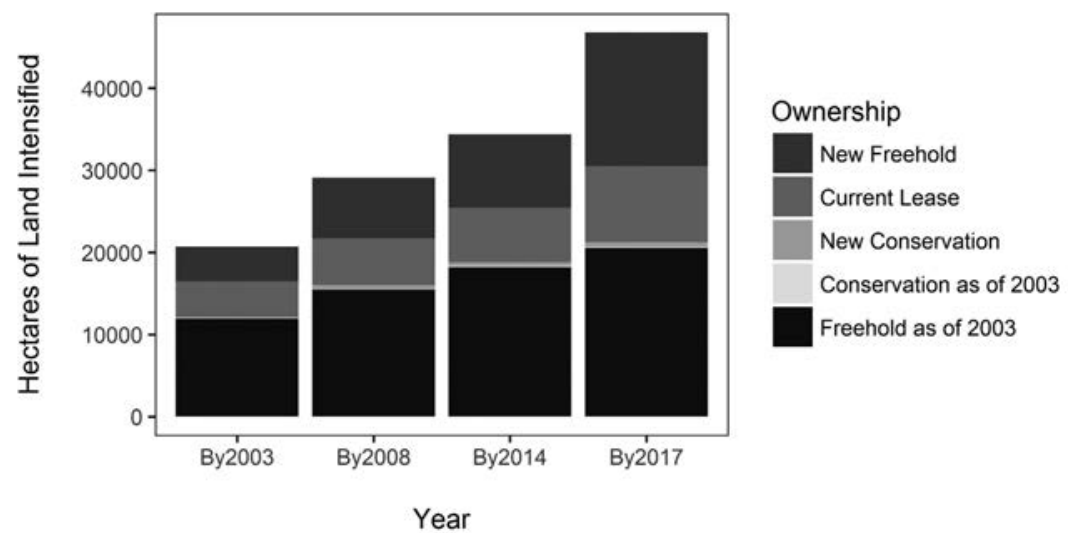

Land intensification in

Figure 2 Hectares of land intensified in the Mackenzie by ownership category from 20032017.

the Mackenzie Basin was initially concentrated in the southern reaches, on existing freehold land. As areas of freehold land expand, so does intensification (as shown in Figures 3 and 4, overleaf). According to Manaaki Whenua's Threatened Environments Categories, land in the 'most threatened' categories that was freehold as of 2003 is intensifying more quickly than threatened environment land in new freehold (Figure 5).

As Figure 5 shows, threatened environments on land that was freehold by 2003 are intensifying more quickly than on new freehold land.

\section{Discussion}

In less than 15 years, agricultural intensification in the Mackenzie Basin has more than doubled in size. In the same time, the area of freehold land has expanded; from just over a third to two-thirds of the Basin. Freeholding opens the door to intensification, but not alone. To understand the acceleration of intensification since 2003, Crown decisions about management of Crown pastoral land must be considered.

Until 2003, two-thirds of the intensification was on land that was already freehold, and one-third was on new freehold or pastoral land. Since 2003, when tenure

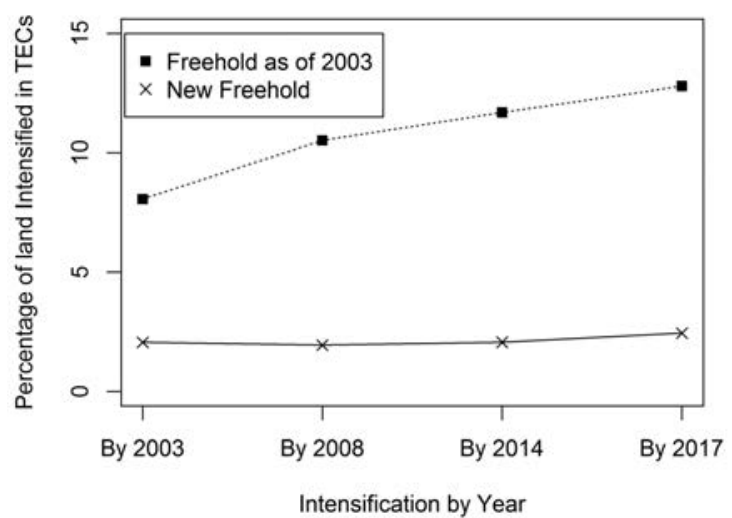

Figure 5 Proportion of land in the two most threatened environment categories on Freehold or New Freehold land that has been intensified.

review deals starting coming to fruition in the Basin, the split reversed. About two-thirds of the intensification has occurred in new freehold (12 000 ha intensified) and current pastoral land (5000 ha intensified). Hence, whilst new freehold may be a bigger player in intensification than pastoral lease, intensification on current pastoral land is still important.

Table 2 Intensification in the Mackenzie Basin by ownership category.

\begin{tabular}{lccccc}
\hline $\begin{array}{l}\text { Land Ownership } \\
\text { Category }\end{array}$ & $\begin{array}{c}\text { Number of } \\
\text { hectares }\end{array}$ & $\begin{array}{c}\text { \% of } \\
\text { Mackenzie Basin }\end{array}$ & $\begin{array}{c}\text { Hectares intensified } \\
\text { by 2003 }\end{array}$ & $\begin{array}{c}\text { Hectares intensified } \\
\text { by 2017 }\end{array}$ & $\begin{array}{c}\text { \% intensified } \\
\text { in this category }\end{array}$ \\
\hline $\begin{array}{l}\text { Freehold as of 2003 } \\
\text { Conservation in 2003 }\end{array}$ & 105600 & 38 & 11900 & 20500 & 44 \\
$\begin{array}{l}\text { Current Pastoral Lease } \\
\text { as of 2018 }\end{array}$ & 72800 & 6 & 100 & 400 & 0.3 \\
New Freehold & 58600 & 21 & 4200 & 1000 & 20 \\
New Conservation & 19100 & 7 & 100 & 600 & 35 \\
Defence Land & 4800 & 2 & - & - & - \\
\hline
\end{tabular}



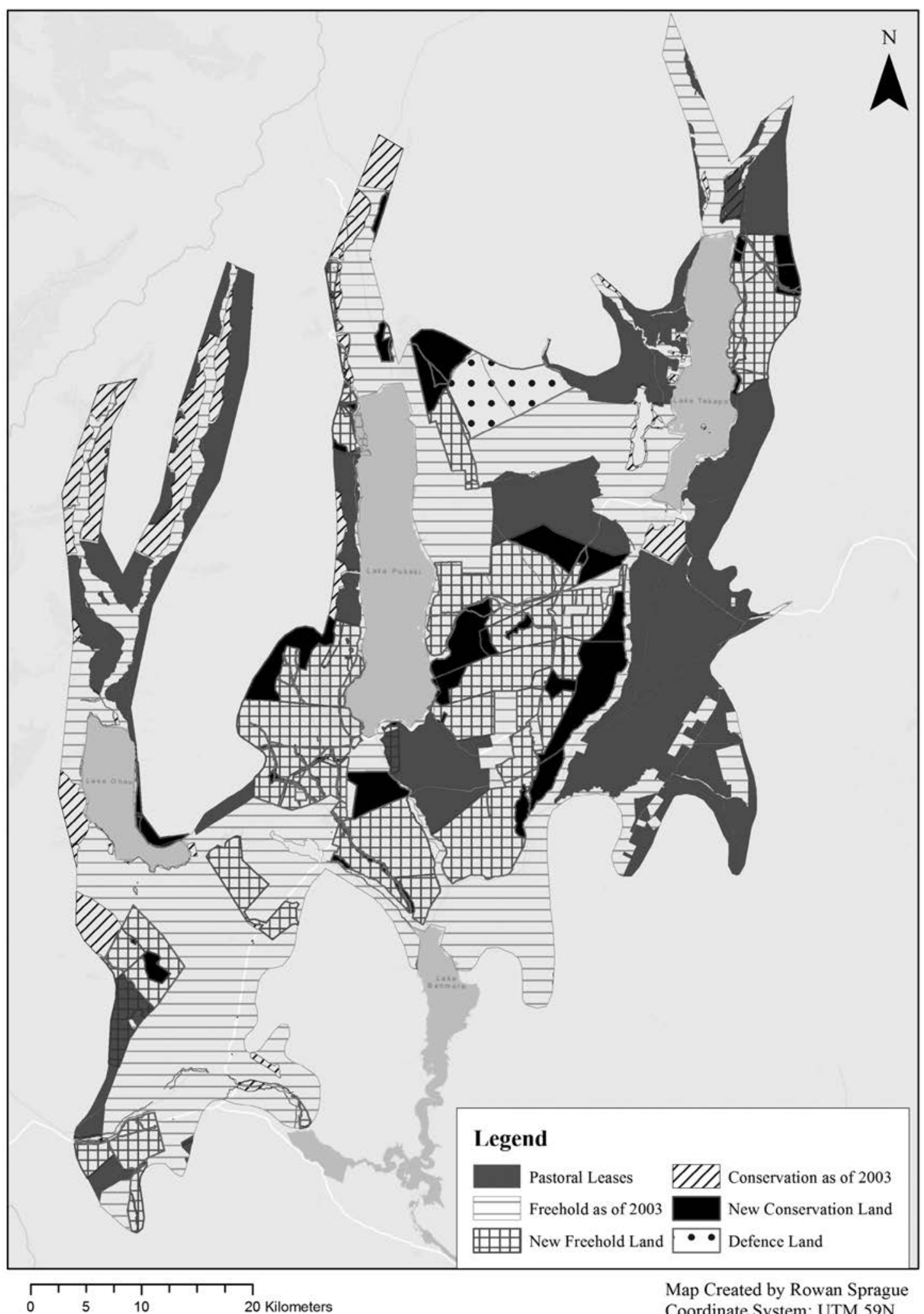

Map Created by Rowan Sprague Coordinate System: UTM 59N

Figure 3 Ownership of land in the Mackenzie Basin as of 2018. 

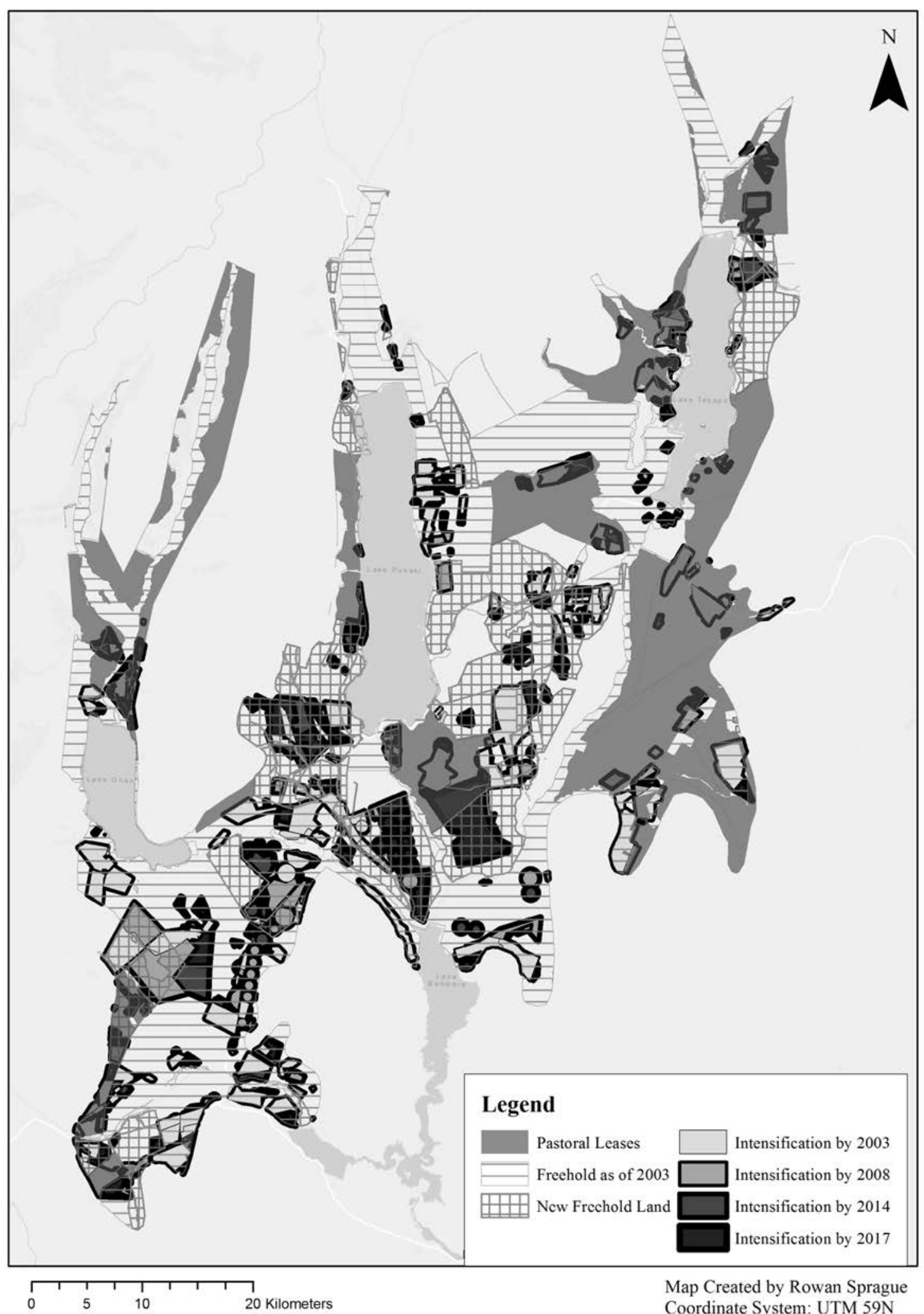

Map Created by Rowan Sprague Coordinate System: UTM 59N

Figure 4 Land intensification by ownership category. Only the Freehold as of 2003, New Freehold, and Pastoral Lease ownership categories are shown to illustrate where intensification has occurred. 
Collectively, Central Government decisions about owning and managing Crown pastoral land explain, or at least allow, two-thirds of the expansion of intensification. Freeholding following tenure review coincides with about half of the expansion. This calls into question the policy of freeholding, just as the Environment Court did in its April 2017 decision. Commenting on tenure review's landscape outcomes, Judge Jackson observed "in our view there is quite a strong ecological (and economic) case for an immediate moratorium (by the Commissioner of Crown Lands) on further freeholding' because without ... a covenant it is difficult to see how the Commissioner of Crown Lands can justify freeholding as consistent with the purpose of tenure review under the CPLA." Current findings further call into question the Commissioner of Crown Lands' decisions regarding discretionary consents, the results of which appear to have accelerated between 2014 and 2017.

The Mackenzie Basin has enjoyed (or endured) heightened media scrutiny and ministerial attention since the Environment Court decision and the change in government (Williams 2018a, 2018c, 2018e). In 2018, there have been at least three separate newspaper editorials calling for an inquiry and a stop to the freeholding (Mitchell 2018c; Timaru Herald 2018; Morgan 2018). In the depths of winter 2018, Greenpeace staged a pre-dawn protest against dairy expansion on Crown pastoral land in the Mackenzie (Quinlivan 2018).

For the first time since the start of tenure review in the early 1990s, the Minister of Lands and the Minister of Conservation is the same person: the Hon Eugenie Sage. She and others have proposed a 'drylands park' of some form in the Mackenzie (Williams 2018b). On 2nd August, the Minister announced the appointment of a High Country Advisory Board, and a 'policy review' of tenure review with 'likely legislative reform' (Sage 2018).

It seems probable that change in some form is afoot. The current results suggest the institutional form that change should take if it is to be enduring and effective. In other words, the results do not suggest what should or should not, happen in the Mackenzie; but they do suggest who has the power to make change happen. Given that Crown land decisions have allowed for two-thirds of the intensification in the Mackenzie, if current patterns in the Mackenzie are to change, then the onus rests with the Crown. Though involved advisory groups can be useful, in this case, it is the Crown itself that can change its patterns of decisions to alter the trends in intensification. The choice and the power reside somewhere in the space between the Commissioner of Crown Lands and the Minister of Land Information.

\section{ACKNOWLEDGEMENTS}

This research was funded by MBIE Targeted Research Grant C10X1503, 'Making SENZS: Richer Decisions for Engaged Communities.'

\section{REFERENCES}

Anthony, J. 2018. US Investor to get NZ residency in return for backing Twizel housing development. Stuff. Fairfax media.

Brower, A.; Meguire, P.; Monks, A. 2010. Closing the deal: principals, agents, and subagents in New Zealand land reform. Land Economics 86: 467-492.

Brower, A.; Page, J. 2017. Freeing the land beyond the shadow of the law: 20 years of the Crown Pastoral Land Act. New Zealand Universities Law Review 27.4A: 975.

Fisher, J.; Acosta, E.; Dennedy-Frank, P.; Kroeger, T.; Boucher, T. 2018. Impact of satellite imagery spatial resolution on land use classification accuracy and modelled water quality. Remote Sensing in Ecology and Conservation 4: 137-149.

Grove, P.; Parker, M.; Gray, D.; Behrens, F. 2015. Land use change on the margins of lowland Canterbury braided rivers, 1990-2012. Environment Canterbury Regional Council.

Hansen, M.; Potapov, P.; Moore, R.; Hancher, M.; Turubanova, S.; Tyukavina, A.; Thau, D.; Stehman, S.; Goetz, S.; Loveland, T.; Kommareddy, A. 2013. High-resolution global maps of $21^{\text {st }}$-century forest cover change. Science 342(6160): 850-853.

Li, X.; Yeh, A. 2004. Analyzing spatial restructuring of land use patterns in a fast growing region using remote sensing and GIS. Landscape and Urban planning 69: 335-354.

Littlewood, M. 2018a, 27th February. Conservation Minister looking into Mackenzie Basin's future. Timaru Herald. Fairfax media.

Littlewood, M. 2018b, 22nd February. Mackenzie Basin ecology in race against intensification. Timaru Herald. Fairfax media.

Littlewood, M. 2018c, 21st February. Major report on Mackenzie Basin calls for greater collaboration. Timaru Herald. Allied Press Ltd.

MacLean, H. 2018, 24th February. Call to revitalise Mackenzie vision. Otago Daily Times. Allied Press Ltd.

Merino Downs. 2017. In the heart of the Mackenzie. Merino Downs. Accessed 1st August 2018. https:// www.merinodowns.co.nz

Mitchell, C. 2018a. 20th January. Half a million hectares sold. The Press, Christchurch. Fairfax media.

Mitchell, C. 2018b. 6th July. After taxpayers paid to get rid of it, farm sells for $\$ 17.5 \mathrm{~m}$. Stuff. Fairfax media.

Mitchell, C. 2018c. 7th July. Handing NZ's heritage to millionaires: the case for an inquiry into tenure 
review. Stuff. Fairfax media.

Mitchell, C. 2018d. 13th July. DOC must explain why it forced out scientist for communicating with the public. Stuff. Fairfax media.

Morgan, J. 2018. 29th January. Inquiry needed into tenure deals. NZ Farmers Weekly. Fairfax media.

Peterson, U.; Aunap, R. 1998. Changes in agricultural land use in Estonia in the 1990s detected with multitemporal Landsat MSS imagery. Landscape and urban planning 41: 193-201.

Quinlivan, M. 2018. Police arrest 12 Greenpeace protesters in Mackenzie District. Stuff. Fairfax media.

Sage, E. 2018. The government's conservation reform agenda. Environmental Defence Society Conference. 1st-2nd August 2018. Auckland, New Zealand. (Proceedings forthcoming).

Seto, K.; Woodcock, C.; Song, C., Huang, X.; Lu, J.; Kauffman, R. 2002. Monitoring land-use change in the Pearl River Delta using Landsat TM. International
Journal of Remote Sensing 23: 1985-2004.

Editorial. 2018. 10th July. Comprehensive review of tenure review should happen. The Press, Christchurch. Fairfax media.

Williams, D. 2017. 13th December. Report slams Mackenzie tenure review. Newsroom.co.nz. Jennings and Murphy.

Williams, D. 2018a, 19th March. Tough Mackenzie farm rules start to bite. Newsroom.co.nz. Jennings and Murphy.

Williams, D. 2018b, 9th May. Mackenzie land sale scrapped. Newsroom.co.nz. Jennings and Murphy.

Williams, D. 2018c, 6th June. Minister mulls clamp on commissioner. Newsroom.co.nz. Jennings and Murphy.

Williams, D. 2018d, 13th July. DOC's culture wars revealed. Newsroom.co.nz. Jennings and Murphy.

Williams, D. 2018e, 6th August. Less talk, more action on high country. Newsroom.co.nz. Jennings and Murphy. 
